\title{
Strangers in a Strange Land: Jewish Memories of Istanbul in the Memoirs of Roni Margulies
}

\section{Esra Almas}

To cite this article: Esra Almas (2021) Strangers in a Strange Land: Jewish Memories of Istanbul in the Memoirs of Roni Margulies, Life Writing, 18:4, 513-525, DOI: 10.1080/14484528.2021.1928811

To link to this article: https://doi.org/10.1080/14484528.2021.1928811

\section{Published online: 15 Sep 2021.}

Submit your article to this journal $₫$

山 Article views: 128

Q View related articles ๘

View Crossmark data $\nearrow$ 


\title{
Strangers in a Strange Land: Jewish Memories of Istanbul in the Memoirs of Roni Margulies
}

\author{
Esra Almas ${ }^{a, b}$ \\ ${ }^{a}$ Katz Center of Advanced Judaic Studies, University of Pennsylvania, Philadelphia, PA, USA; ${ }^{b}$ Department of \\ Turkish Literature, Bilkent University, Ankara, Turkey
}

\begin{abstract}
This essay investigates the role of Istanbul, and of drastic urban change, in the shaping of a particular form of autoethnograpy, and, reciprocally, the role of life writing as a particular constituent of the city's urban imaginary. The focus is the upscale cosmopolitan neighborhood of Nişantaşı, as seen largely through Jewish eyes, in the memoirs by the dissident writer and poet Roni Margulies: Jews Go Wild on Sundays [Margulies, Roni. 2006. Bugün Pazar Yahudiler Azar [Jews Go Wild on Sundays]. Istanbul: Kanat.], and My Family and Other Jews [Margulies, Roni. 2018. Ailem ve Diğer Yahudiler [My Family and Other Jews]. A published poet, journalist and member of the Turkish Workers Party, Margulies has been active in Turkey as a public intellectual. His memoirs are poetic, political, and humorous. They combine literary sensibilities with political commitments, addressing multiple tensions that have molded his identity as a Turkish Jew. The focus on Jewish lives provides a kaleidoscopic perspective to the city, the neighborhood, and to the practice of writing from the periphery. Retrospective but not nostalgic, Margulies takes issue with the notions of home and homeland, revealing the complexity of affinities. Margulies's memoirs help reconsider the parameters of autoethnography, a mode of reading that questions not only the links between the auto and ethnos, but also the hierarchies between minor and major, center and periphery.
\end{abstract}

\section{KEYWORDS}

Urban imaginary; modern Middle East; Jewish diaspora; Turkish literature; Istanbul; memory studies

\section{Introduction}

The modern city is associated with loss and erasure. Istanbul is no exception. Its fraught histories in the twentieth century and hypertrophic transformation in the twenty-first turned it into a megalopolis of mythic proportions, disorienting visitors and inhabitants alike. The narratives on the city respond to the sense of loss that accompanies change; some put it to use as the necessary distance one takes from forms and spaces of identity, to question all. This essay investigates the role of Istanbul, and of drastic urban change more generally, in the shaping of a particular form of autoethnography, and, reciprocally, the role of life writing as a particular constituent of the city's urban imaginary. The focus is the upscale cosmopolitan neighbourhood of Nişantaşı1, as seen largely through Jewish

CONTACT Esra Almas esra.almas@gmail.com

This article has been republished with minor changes. These changes do not impact the academic content of the article. (c) 2021 Informa UK Limited, trading as Taylor \& Francis Group 
eyes, in the two popular memoirs by the dissident writer and poet Roni Margulies (2006, 2018): Jews Go Wild on Sundays (Bugün Pazar Yahudiler Azar), and My Family and Other Jews (Ailem ve Diğer Yahudiler). ${ }^{1}$ A published poet, journalist and longtime member of the Turkish Workers Party, Margulies has been active in Turkey as a public intellectual. His memoirs are poetic, political, and humorous. They combine literary sensibilities with political commitments, addressing multiple tensions that have moulded his identity as a Turkish Jew. Margulies's focus on Jewish lives in Nişantaş1 provide a kaleidoscopic perspective to the neighbourhood and to the practice of writing from the periphery. Retrospective but not nostalgic, defiant and dissenting, Margulies takes issue with the notions of home and homeland, revealing the complexity of affinities. Margulies's memoirs do not simply provide oblique angles to a peripheral metropolis and its literary cityscape, they also question the parameters of autoethnography.

\section{Autoethnography in the metropolis}

Memory is malleable, the experiences of longing and belonging are myriad, and its writing is multiple. The many forms of writing make autobiography a suitable genre, Seyhan $(2001,96)$ contends, to 'conjugate all the tropes of exile'. Memoirs with emphasis on cultural geographies provide insights into how writing shapes the self, space, and the community in response to the problem of humankind's self-orientation, a question (Erich Auerbach [1948] 2003), a German Jew poses in Mimesis, written while in exile in Istanbul. This essay suggests that in Istanbul self-orientation, exile, and belonging are the primary concerns of locals alike. Situated at the intersections of the personal and the public, the local and the foreign, the centre and the periphery, life writing may incorporate diverse forms of homelessness, including the ones at home. When written from the margins, and questioning the sense of home and belonging, autobiography becomes a political gesture.

An exploration of the self through the community, the memoirs in focus are what Michael Fischer $(1986,232)$ refers to as ethnic autobiographies: cultural critiques and affirmation of pluralism, which encourage the reader 'to self-consciously participate in the production of meaning'. Autobiography does critical autoethnography as defined by Françoise Lionnet (1989) and Mary Louise Pratt (1991, [1992] 2008): an effort to salvage one's own 'vanishing' culture and share it with a wider, and possibly international audience. This essay uses Pratt's formulation as its point of departure, introducing the arts and perils of the contact zone in a Turkish setting. Indeed, as Edhem Eldem (1999) points out, Istanbul's imperial history has made it a space of contact, which involves brokerage and mediation, as well as conflict and rivalry between different forces. Eldem $(1999,138)$ defines Ottoman Istanbul as an unusual contact zone through a variety of terms, which include, but cannot be reduced to mere opposition: 'encounters between cultures and ethnicities, conflicts between political goals and economic interests, mixtures between creeds and mentalities, equilibria between opposing tendencies, and, most of all, a constant process of brokerage and mediation between actual or potential rival forces'.

This essay draws attention to autoethnographic moments: expressions of conflict, critique, parody, and resistance in terms of the tensions between the self and society. 
Nonetheless, focusing on the representation of a peripheral metropolis by a member of a significant minority, and by that I am referring to visibility and cultural capital, the essay points to the complexity of the term as a conceptual tool, thereby nuancing Pratt's perspective and the oppositions the term entails. Autoethnography, I suggest, is a productive mode of reading that questions not only the links between the auto and ethnos, but also the hierarchies between minor and major, centre and periphery. Referring to Margulies's memoirs as autoethnographic writing nods to the importance of rhetoric as a mode of cognition and as a constituent of cultural and historical continuities (Clifford and Marcus 1986). This reading of autoethnography as a political gesture and a potential is inspired by Françoise Lionnet's $(1989,108)$ definition of the term as 'a space of resistance between the individual (auto-) and the collective (-ethno-) where the writing (-graphy) of singularity cannot be foreclosed'. Through emphasis on dialogue and diversity, autoethnography may challenge unitary visions, evoke the perils and potential of coexistence, and multiply the voices of the city.

\section{Istanbul}

Istanbul's metamorphosis during the twentieth century has been drastic. The demise of the Ottoman Empire in 1918 was closely followed by the proclamation of the Turkish Republic in 1923. The multiethnic and multireligious composition of the millennial metropolis, with Greeks, Jews and Armenians constituting the majority, changed substantially with the increasingly nationalist policies of the Republic (Yerasimos 1992, 12). Today, Istanbul's imperial past is mostly a marketing strategy. Historic neighbourhoods have morphed into tourist attractions nearly devoid of local residents; other areas are caught in an ebb-and-flow of gentrification. Only a few neighbourhoods have resisted gentrification, or reciprocally, have retained well-to-do residents for more than a century. Nişantaşı is one of them (Neyzi 2009). A hunting spot for the sultans in the late-eighteenth century, the area became popular with the Ottoman aristocracy following relocations of imperial palaces to its vicinity in the nineteenth century, and after the ascendance of nearby Pera to the cosmopolitan centre of the city. In the early twentieth century, the vicinity became popular with middle- and upper-class non-Muslims, such as upwardly mobile Jews and the Ma'minim, the devotees of the mystical messianic rabbi Sabbetai Ts'vi (1626-1676), who converted to Islam in his footsteps in the 1680s, and whose religious practices blend Islam and Judaism. The Ma'minim, also known as the Dönme, or Sabbateans, left Salonika after the city became Greek territory in 1913, and in the 1920s, due to the population exchange between Greece and Turkey [Baer (2010); Sertel (1994)]. One of the most centrally located neighbourhoods of the city, Nişantaşı is well endowed with schools, parks, and hospitals, and has appealed to exiles, migrants and refugees who sought, and could afford the lifestyle it offers. Today, it is a popular shopping destination boasting high-end designer and stereo stores, cafes, and stately apartments. Its streets are lined with spacious flats in five-to-six-story modern apartments, occasional mansions, art nouveau facades, and schools with a centennial past. The smaller stores on its tree-lined side streets-such as watchmakers, tailors, record and bookstores, charcuteries, and art galleries-confirm its enduring attraction as a centrally located and very desirable place to live. Retrospection in the urban context resonates with Svetlana Boym's (2001, 75) contention that 'the city imagines its future by improvising on its past'. In Istanbul, 
the traces of the past are hard to find, and the present is uncanny, but less so in a neighbourhood like Nişantaşı.

For Nişantaşı to be more than an affluent shopping district in the urban imaginary, stories of its everyday spaces and practices need to be retold, if not invented. Nişantaşı is very much associated with the Turkish novelist and 2006 Nobel laureate Orhan Pamuk. In Istanbul: Memories and the City (2005), a portrait of the writer as a young man, interwoven with literary and artistic representations of Istanbul, Pamuk identifies with the city. ${ }^{2}$ Istanbul makes Pamuk what he is, and he sees in Istanbul what he expects to see (Almas 2012). Impressions of the neighbourhood are weaved into the life story. Childhood memories in Nişantaşı are embellished with anecdotes of feuding aristocrats and how their mansions, lifestyles, and families perished. The centrally located apartment he grew up in, where each member of the family was given a separate flat by the matriarch, is a continuation of Ottoman traditions. Perhaps a more iconic structure is Alaaddin's grocery store: a key setting in Pamuk's breakthrough Black Book (1994), and a regular feature in most of his work, the grocery store is a cornucopia, evoking 1001 Nights and revealing the affluence of the neighbourhood, but also materialising the hodgepodge of the city. Nişantaşı responds to the longing for Europe, as it looks like an affluent neighbourhood in a Western or Central European city. It also functions as a base from which the writer sets out to explore the historic parts of the city.

A parenthesis on the rhetoric in Istanbul may explain the politics of periphery in autoethnographic writing. Pamuk's memoir, part travel book and part cultural history, is a meditation on writing as a non-western. Pamuk $(2005,261)$ identifies with the Western traveller, 'plunging with him into the thick of life, counting, weighing, categorising, judging and in so doing often usurping their dreams, to become at once the object and the subject of the Western gaze'. Seeing the city from within and sometimes from without, his perspective embodies the autoethnographer in the sense defined by Mary Louise Pratt ([1992] 2008): writers of the contact zones in the colonies, not quite belonging to this place, and not quite a stranger. Pamuk, with his westernised upbringing and education, feels obliged to read about his city-self through visitors' accounts: he reflects on himself through an 'other' eye/I inscribed by western discourse (226). Split subjectivity becomes a means to appreciate Istanbul's rich traditions and being 'Under Western Eyes' a poetic opportunity to pluralise the self. Pamuk's predicament is that his descriptions of the city-written from a western perspective but with intimate knowledge of and deep passion for the east-involve conflicting affinities and affiliations. Although considered the foremost writer of the city, at 'home' he is considered an outsider who writes for an international literary market.

Born and raised in the same neighbourhood to families of similar social background, attending the same primary school and college, Margulies and Pamuk write autobiographical texts with similar concerns. Grounded in Nişantaşı, and in memories of an Edenic childhood, both pay homage to the neighbourhood and the communities they were born into. Both have dissenting views and come from wealthy families, yet both are outsiders to the community they are addressing, speaking within and without. Nonetheless, they come from different collectivities: majority and minority. Their status as writers is also different. Pamuk is a bestselling writer with international acclaim. Margulies is a published poet, with poems written almost like prose, and his work is known in smaller circles. His popularity resides in his political activism and critique. Linking the two 
evokes an imbalance because of the difference in status. Yet this imbalance provides an opportunity to reorientate the parameters with which we view the distinctions between centre and periphery, insider and outsider.

\section{Writing the Jews}

Persistently considered guests rather than locals, the Jews of Turkey have been seen as markers of Ottoman tolerance following the expulsion from Spain in 1492. Enforced estrangement speaks to a homelessness that long predated the modern urban experience. Today, the diminishing Jewish community residing in Istanbul is closely associated with the bygone cosmopolitanism of the city. Recollection necessitates an encounter, if not reconciliation, with discord. Narrating the multiple experiences of coexistence, rather than a constructed nostalgia means, as Leyla Neyzi (2002, 142) contends, 'confronting the exclusionary aspects of national identity, and its high cost for individuals'. Recent memory and ethnographic work on Jewish identity in Turkey takes these views to task (Baer 2010; Brink-Danan 2012; Şeni 2013). Rifat Bali (2012, 2018, 2019) edited, published and wrote multiple volumes on Turkish Jews, and he runs Libra Books, a publishing house devoted to the study of non-Muslim minorities in Turkey. The edited collections of testimonies and memoirs by Bali (2012, 2018) document Jewish lives and neighbourhoods, critiquing the policies and practices that led to the drastic changes in the ethnic makeup of the city. Women writers place emphasis on memory as a collective process with political and practical implications. Rita Ender (2016, 2018) explores the material and affective component of Jewish identity in contemporary Turkey in Ismiyle Yaşamak (To Live with One's Name), and Aile Yadigarları (Family Heirlooms). Rita Ender (2018); Aylin Kuryel and Raşel Meseri (2018) focus on the experience of Jewish identity in Türkiye'de Yahudi Olmak: Bir Deneyim Sözlüğ̈̈ (Being Jewish in Turkey: A Dictionary of Experience). Highlighting the everyday practices of coexistence and conflict, they critique the policies which led to the drastic changes in the city's ethnic makeup (Bali 2019). A more wide-reaching example is the website Avlaremoz, meaning 'let's speak' in Ladino, a cultural initiative that takes its cue from the Sephardi experience in Turkey to counter and expose forms of racism and notably anti-Semitism.

The memoirs by Roni Margulies (2006, 2018), My Family and Other Jews, and Jews Go Wild on Sunday highlight the experiences associated with the minority position, ranging from exclusion to alienation, which ultimately led to the drastic changes in the makeup of the city and to departure of so many of its Jews. The accounts of the plights and pleasures of Jewish life in Istanbul conjoin archival and ethnographic impulses, reinscribing lost lifestyles in the political, economic, and cultural fabric of the city. Margulies refers to his texts as narratives, conditioned by the need to preserve a vanishing culture in writing, and the need to tell a good story; classifying them as memoirs is an editorial exigency (Avlaremoz 2021). My Family and Other Jews, an extended reprint of his 2000 memoir Gülümser Çocukluğum Ardımdan (My Childhood Smiles After Me). The narrative includes shards of memories organised according to places frequented in childhood, and to decisive experiences like school, love, loss, friends, and books; their affect is explored in verse. The memoir is framed by two stories of displacement: the divergent trajectories of the grandmothers and a letter to his father as a young engineering student in the United States. In-between, we read about bus routes now extinct, 
records loved, and loves lost. Written as a 'love letter' to the Jews of Istanbul and addressed to a Turkish audience, Jews Go Wild on Sunday is an ode, humorous and nostalgic at times, to the Jewish lives in Turkey. The title is a case in point. It repeats an obsolete expression, which marks the difference between Jewish and Christian holy days, and which makes sense, with its humorous rhyming in Turkish of pazar, Sunday, and azar, go wild. By using a derogatory remark as the title, the narrative appropriates the unique experience of being Jewish in Turkey.

\section{Jewish Nişantaşı}

Popular with affluent Jews, Nişantaşı in some regards is an extension to Şişli, a neighbourhood with a sizeable Jewish community. Its synagogue Bet Israel is still functioning and rigorously guarded. Right by the synagogue there are cultural centres, especially for the young. Nişantaşı is also an extension of Teşvikiye, the aristocratic neighbourhood initiated by the Porte and inhabited by the grand bourgeoisie, including Jews. An earlier resident of Nişantaşı with a trajectory somewhat similar to Margulies is Moris Gabbay, who grew up in the neighbourhood in the 1920s, attended Robert College, and later became a member of Turkish Worker's Party. Gabbay's (2013) memoir, Cumhuriyet'le Beraber Büyüdüm (I Grew Up with the Republic) was published as part of the oral history project initiated by the Turkish Workers' Party. Gabbay's life and commitments were unusual, yet he was one of the many who grew up in the cosmopolitan Nişantaşı and its surrounding neighbourhoods, referred by Rifat Bali (2018) as Yahudi Mahalleleri, the Jewish neighbourhoods.

Jews Go Wild primarily chronicles the good life of Margulies's extended family along the shores of the city and in Nişantaşı. The narrative highlights the lifestyles shaped by the topography and the metropolitan past, lost due to changes in demographics and urbanisation. In the privileged world of his childhood, he argues, the divide between the wealthy and the middle classes was not as drastic as it is today. Doting grandparents, summers in the seaside suburbs along the Marmara Sea, private schools, and friends with multiethnic backgrounds testify to the spirit of the time when life was easier. Margulies $(2006,23)$ reclaims the world of childhood, referring to Istanbul as saray, a palace, rather than han, an inn.

For Margulies, Nişantaşı appears as a token of the cosmopolitan past that seeped into his childhood. Margulies hints at the substantial Jewish presence in the neighbourhood through multiple details. The stately apartment the paternal grandfather built on one of the main streets of the neighbourhood with Jewish and Sabbatean friends, adds to the visible, if largely unknown, legacy of the community. Early memories place emphasis on the multiethnic makeup of the neighbourhood, providing glimpses of fading lifestyle. The primary school he attended in the neighbourhood, established in Salonica by the Sabbatian community and transferred to Istanbul, is marked with harsh discipline and with multiethnic classmates. We learn that at Şişli Terakki, the primary school founded by the Ma'aminim, then the British Highschool, and finally at the American Robert College, many of his classmates had Armenian, Greek and Jewish background. Both schools have given him a sense of an insular and cosmopolitan Istanbul that was already disappearing, and attending Robert College, already a tradition in the family, was key to personal development. Margulies's memoirs add to the multidirectionality 
of Nişantaşı's memories, to borrow Michael Rothberg's (2009) term on memories that pluralise and politicise remembrance. They reappropriate the neighbourhood, reinscribing its multiethnic demography and cultures in the fabric of the city.

\section{The grandparents}

Margulies's memoirs bring grandparents into focus, reflecting Ashkenazi and Sephardi lineages. Both moved to Istanbul in the 1920s, and their diverse backgrounds exerted a substantial impact on his identity. My Family and Other Jews (2018) starts with an account of the trajectories of the maternal and paternal grandmothers, a Sephardi and Ashkenazi, who migrated to Istanbul in early twentieth century from Izmir and Vienna respectively. Even though both lived in Nişantaşı, they would never have met had it not been for their children's marriage. Entitled 'The Story of Two Unpretentious Lives', the section highlights the variegated trajectories of these women who, living through the fall of empires, ended up settling in the same neighbourhood. Neither spoke Turkish. The paternal grandmother's foreignness is a source of inspiration. Margulies $(2018,82-84)$ assumes her voice in a set of poems entitled 'Letters to Poland, May 28th, June 2nd, June 8th, 1925' perhaps in an attempt to connect with postmemory and pre-war Poland.

The grandparents' story provides an outlet to illustrate the diversity of the community. Margulies's paternal grandparents are Ashkenazim. His grandfather, originally from Poland, fought for the Habsburg Empire in World War I; when the Empire disintegrated, he returned and fought for Poland against the Soviets. He fell in love with the daughter of the doctor of his regiment, went to Vienna to study engineering, found work in Berlin, and came to Istanbul with his wife in 1925. They never went back to their old country. They also never mentioned the loss of their family in the Holocaust. The grandfather, partner in a successful trading venture, lived in a stately apartment on a prestigious street in Nişantaşı, spent part of the winter in Switzerland and funded the studies of his son and grandson in the United States and in the United Kingdom, respectively. The extraordinary trajectory of the grandfather evokes the plights of European Jews in the first half of the twentieth century. Yet, unlike many, including his immediate family, it ended happily. In this Odyssey of success and survival, Istanbul emerges as an improbable home. It is also a city of coexistence that accommodated a nexus of Jewish communities, refugees, immigrants and locals.

The story of Margulies's maternal grandparents highlights the complex trajectories of Turkish Sephardi. Both are from Tire, an agricultural town roughly 50 kilometres inland in Izmir that dates back to antiquity. A rural family that urbanised with modernisation, they first moved to Izmir, and with the advent of the Republic, to Istanbul. His maternal grandmother from Izmir, fluent in Ladino and in French, had a sociable life, frequently meeting with her friends, probably Sephardi women, to play cards. The maternal side allows the writer to trace the Francophilia of the Sephardim. Not the most prosperous community in the Ottoman Empire, the Sephardim adopted French as their preferred language by establishing Alliance schools in the late nineteenth century through collaboration with French Jews (Rodrigue 1990). The initial cause forgotten, Francophonie led to a feeling of superiority. Middle Eastern Jews were associated with both the coloniser and the colonised, a critique brought forward by Albert Memmi. The result, Margulies 
(2006, 19-20) claims, is the ambivalent identification with the West of a group that inhabited the Middle East much longer than the Turks.

\section{Jewish difference: lehli and spanyol}

A key theme and vantage point in Margulies's narratives is the minority position. He writes from the margins. His duality, however, is not simply between East and West, Jews and Muslim Turks, but between Sephardi and Ashkenazi, East Mediterranean and Eastern European Jews, nationalists and humanists. His memoirs diversify the Jewish communities, starting with the different Jewish traditions into which he was born: 'lehli' ve 'spanyol', Lithuanian and Spanish, the Ashkenazi and the Sephardi, gefilte fish and kaskarikas, fish-based dishes of the Ashkenazi, as opposed to the vegetable dishes of the Sephardi.

Margulies's narrative also features the differences within the Jewish community of Istanbul. Accounts of the poor residing in the traditional Jewish neighbourhood, de la kula in Galata, of religious Jews, and of the underprivileged who left for Israel, debunk stereotypes and nationalist discourses on both sides. The panorama of the period and beyond attests to heterogeneity-including the poor and the wealthy, the traditional and the westernised. In these accounts, the present community is losing its distinctive traits: marriages and neighbourhoods are mixed, and Turkish has increasingly replaced Ladino, introduced earlier, as the mother tongue. Ladino expressions may reveal a peculiar perspective, Margulies (2006, 14-15) contends: se levantaron los pipinos para harvar el bahcevan articulates the image of cucumbers rising up to beat the gardener, which is both idiosyncratic and humorous. The text includes an array of TurkishJewish types, contextualised: the pasharos, the moneylenders, the rich entrepreneurs, and the foreign connections. There are also references to the Jewish bourgeoisie as community leaders. A key question in Jews Go Wild is difference: are Jewish rituals, languages, and customs a sign of irreconcilable differences, or could they be part of Turkish identity? Differences are few and keep diminishing, yet feelings of foreignness and alienation, he bemoans, are still strong (101). Providing a unique perspective on the policies and practices that promoted conviviality but also precipitated its loss, memory narratives deploy, in the words of Homi Bhabha $(1996,58)$, 'the culture from which they emerged to construct visions of community, and versions of historic memory that give narrative form to the minority positions they occupied'.

Margulies's portrayals of Jewish lives are demarcated by his interests. Apparently and affectively secular, his narratives hardly mention the religious aspect of Jewishness. There are almost no references to synagogues, to Jewish holidays, or to observance of religious rituals. Bar Mitzvah is an opportunity to receive presents (2018, 92-95). He mentions childhood friends who became orthodox, but who left either for Israel or for the United States. Conviviality is embraced by way of obscuring, or perhaps ignoring, national myths and religious rituals. Margulies repeatedly critiques Israeli policies, thereby distancing himself from nationalist Jewish political identity. Nonetheless, he intimates a transcultural experience of elective affinities by referring to a constellation of Jewish writers and thinkers. To illustrate the difference between American, and, more generally Mediterranean Jews, Margulies (2006, 90) nominates Philip Roth's ([1993] 1994) satirical idea outlined in his comic masterpiece Operation Shylock of Poland as 
alternative Jewish homeland. Here it is worth remembering that Roth's fiction has been celebrated not only for its humour, but also for its ethnographical qualities (Ortner 2006). In a similar manner, when explaining the demeanour of a Francophile aunt, Margulies refers to André Aciman's ([1996] 2007) memoir, Out of Egypt. Aciman's sketch of his grandmother as the princess of the family attests to the ubiquity of Francophilia among the Sephardim in Egypt and in Turkey alike, a point repeated multiple times in the narrative (Margulies 2006, 14-15).

Documenting a minority marginalised yet not insignificant, Margulies's work does not fit the hierarchies of centre and periphery, coloniser and colonised, the parameters which typically qualify autoethnographic writing. The rhetoric can be traced back but cannot be fully explained as collaboration with and appropriation of the idioms of the conqueror (Pratt [1992] 2008, 7). Margulies identifies as a Turkish citizen, yet his discussions are not limited to Turkey. The constellation of writers he invokes makes the narrative part of the world republic of Jewish letters and theory, but in Turkish. As ethnographic memoirs with a metropolis as the prominent feature, Margulies's writing resonates with Buzzard's (1997, 450) definition of metropolitan autoethnography, 'the romance by which modern Western societies seek to know themselves as cultures'. Yet, the term does not fully work in this case: the metropolis in question is not part of the modern West, nor is the writer of the dominant group associated with the metropolis.

\section{Strangers at home}

Margulies's memoirs are meditations on forms of foreignness. In Jews Go Wild, the writer $(2006,88)$ probes the reasons why he is considered a stranger in the land where he and his parents were born and raised, and to which he is emotionally attached and politically engaged. The reasons are manifold. Frenchified Jewish first names carrying on the traditions of his maternal family, combined with a Yiddish-sounding surname of the father, may be the reason why he continues to be asked about his mother tongue and why his poetry books are placed in the 'foreign' section of bookstores (85-86). They also point to the reforms in language and the enforced insistence on the use of Turkish during the early years of Republic made it an arena, as well as a much-researched area of literary homelessness (Hülya Adak 2008).

Margulies's departure for London immediately after college in 1972 further refracts the feeling of estrangement and exclusion. Life in London has augmented the feelings of alienation and homesickness, yet it is barely mentioned. In My Family and Other Jews (2018, 113), London welcomes everyone as a local. We also find out that Margulies returned to Istanbul, to the neighbourhood he grew up in, preferring to be seen as a foreigner in the city he feels attached to and identifies with, rather than continuing to live in a city for which he does not feel affinity (113). Similarly, the poem 'Strange Days', dedicated to a close friend who passed, reminisces their discovery of The Doors and their iconic song, 'Strange Days', repeating its haunting lines, 'people are strange when you are a stranger', and juxtaposing it with the uncanniness of the death of a close friend (119). The poem, written in London on a foggy evening, turns into a eulogy for the 'bright boys of Istanbul in the 70s ready to conquer the world' (122). London, as Margulies (1996) describes in his poem 'A Tale of Two Cities', have served him as a stage showcasing a play in English, with the majority of the actors Turkish. 
Narratives help reconsider the implications of absence, distance, and loss when relating to hearth and homeland. Margulies's descriptions evoke the modernist and contemporary tropes of relating to the city, and a characteristic feature of Orhan Pamuk's work. Revealing his self-proclaimed status as a resident outsider, Pamuk recognises his identity in estrangement by way of finding company with other writers' geographic and intellectual estrangement, notably along the lines of Erich Auerbach, Theodor Adorno ([1951] 2006), and Edward Said (1993). Homelessness emerges as a moral value, the distance one takes from forms and spaces of affiliation, affinity, identity and identification, to question all without reserve.

Margulies's take on homelessness at home places emphasis on the ethnos, grounding the feeling in the experience of Turkish Jews. In a long passage on the Turkishness of the Jews of Istanbul, Margulies refers to generations of Jews settled in major cities and towns in Ottoman and Republican Turkey, including Salonika, the birth city of Ataturk. He places emphasis on the difference in ethnic background, humorously harking back to the mythic roots of Turks in Central Asia and its tribes. The cultural identities of Turkish Jews are shaped equally by Jewishness, as religious and ethnic identity, and by the land and its peoples. Margulies $(2006,106)$ writes, in a playful tone, Türkleştiremediklerimizdendirler, ama Türkiyelileşmişlerdir: 'We have not been able to Turkify them, yet they are Turkeyfied. They may seem slightly different, but despite the appearances, they are not foreigners. They are locals'. The passage encapsulates many of his arguments on cultural identity, with puns on stereotypes and syntax. The narratives between the past and the present, Turkey and 'the West', Jewish and Muslim communities, add humour to discussions on locality and belonging.

The definition of a resident conflates the joys, conflicts, and the constant flux the city is associated with to ultimately suggest an idiosyncratic definition of an Istanbullu: strangers in strange lands. Istanbul obscures its residents, past and present, destroys some, preserves others, but reshapes them all according to its own will. The city starts each day as a new and strange country. Margulies $(2018,109)$ contends: Bizler İstanbul'un yerlileri kendi ülkemizde hep yabancıyıdır 'We the locals of Istanbul are strangers in our home city'. Margulies's definition resonates with the passage in Exodus where Moses decides to call his son Gershom because he had been 'a stranger in a strange land' (2: 22). With contemporary Istanbul as the setting, the phrase conjoins modernist and biblical tropes, thereby evoking the sacred and the secular, and turning the metropolis to a mythic land. A remarkable point in the above account is the understanding not only of the self, but of all Istanbullu as strangers at home, recalling the melancholic tradition of estrangement as part of an urban identity.

Istanbul's fraught histories feature as part of the poetics and politics of memory. The city's cataclysms and constant change are transformed into means of generating further possibilities of textual stratification. Istanbul may be an alienating metropolis; yet it is the space of imagination, a locus of both individual and cultural identity, and poetry. In a manner that resonates with Orhan Pamuk and Ahmet Hamdi Tanpınar, prominent novelists of modern Istanbul, Margulies places emphasis on the perpetual transformation of the city. Nonetheless, unlike Tanpinar who equates change with art, Margulies's focus is estrangement. A true local is a perpetual stranger - always longing, yet never at home. Writing emerges as a means of befriending and benefiting from, if not inhabiting, homelessness. Cultural identity is not simply received, but also interpreted, if not invented, in writing. 


\section{Conclusions}

Autobiographies in focus do not simply describe a personal story, a neighbourhood or its communities; they document the ambiguities of the Republic, the city, and of belonging. The personal and the poetic are therefore political; autobiography is ethnographic. Reviewing the changing forms of coexistence, and the myriad forms of homelessness that the same cultural geography can invoke, the memoirs reveal what anchored those who stayed, in mind or in body, to the city. Surviving in a world without hinges points to the possibility of making any place a home and bridging multiple divides. Istanbul's inhabitants appropriate its millennial past in order to create their own urban space.

Margulies's memoirs straddle the divide between Jews and Turks, Sephardim and Ashkenazim, conservatives and progressives. Writing for an audience in a language to which he is considered a foreigner and about a community from which he feels alienated, his affinities are complex, if not defiant. Attachment and alienation, East and West, home and exile are not fixed, nor are they easily identifiable. Their malleability, however, is what generates the urge to write the self and the city. The emphasis on memories of Istanbul solidifies the proposition that the space one inhabits, as unstable as it is, is an inescapable constituent of the self. Affinities, like homes, are established in the mind, and writing, in all its guises, is their lasting manifestation. Materialising multiple memories, the narratives discussed in this essay help sustain hope for the possibility of an inclusive city.

\section{Notes}

1. Translation of these titles and all subsequent translations from the original Turkish are by the author of this article.

2. Due to space limitations, English translations are used.

\section{Acknowledgements}

Part of this essay was written during my fellowship at Herbert Katz Center of Advanced Judaic Studies at the University of Pennsylvania during 2018-2019. I am grateful to Jack Kugelmass for his help in structuring some of the arguments in this paper. I also thank the anonymous editors of Life Writing for their comments.

\section{Disclosure statement}

No potential conflict of interest was reported by the author(s).

\section{Notes on contributor}

Esra Almas is an Assistant Professor of Comparative Literature at Istanbul Sehir University, Turkey. She completed her PhD in the Amsterdam School for Cultural Analysis at the University of Amsterdam, where she taught in the department of Literary Studies. She has worked as a translator, moderator and organiser for PEN International, Amsterdam University Cities Project, and Netherlands Institute in Turkey. She was a research fellow at the Herbert Katz Center of Advanced Judaic Studies at UPenn. Her research focuses on the intersections of memory studies and urban imaginary, in particular diaspora narratives, modern Turkish literature, urban imaginary, and 
women's intergenerational writing. She has published on Istanbul's modernist literary cityscape, melancholy and exile.

\section{References}

Aciman, André. [1996] 2007. Out of Egypt. New York: Picador.

Adak, Hülya. 2008. "Introduction: Exiles at Home-Questions for Turkish and Global Literary Studies." PMLA 123: 20-26.

Adorno, Theodor. [1951] 2006. Minima Moralia. London: Verso.

Almas, H. Esra. 2012. "The Locus of Identity: The Self and The City in Orhan Pamuk's Istanbul: Memories and the City." In Life Writing Matters in Europe, edited by Marijke Huisman, Anneke Ribberink, Monica Soeting, and Alfred Hornung, 145-161. Heidelberg: Universitätsverlag Winter.

Auerbach, Erich. [1948] 2003. Mimesis: The Representation of Reality in Western Literature. Princeton, NJ: Princeton University Press.

Avlaremoz.com. "Roni Margulies ile Ailem ve Diğer Yahudiler Üzerine Söyleşi” (“An Interview with Roni Margulies on My Family and Other Jews"). www.avlaremoz.com/2018/09/16/ronimargulies-ile-ailem-ve-diger-yahudiler-uzerine-soylesi.

Baer, Marc D. 2010. The Dönme: Jewish Converts, Muslim Revolutionaries, and Secular Turks. Stanford, CA: Stanford University Press.

Bali, Rifat. 2012. Model Citizens of the State: The Jews of Turkey during the Multi-Party Period. Langham: Rowman and Littlefield.

Bali, Rıfat. 2018. Mazide Kalmış bir Yaşam Tarzı: "Yahudi Mahalleleler," [A Lost Lifestyle: Jewish Neighborhoods]. Istanbul: Libra Yayınevi.

Bali, Rifat. 2019. Yolları Kesişen Aileler ve Hayatlar Baliler, Filozoflar, Diğerleri ve ... Ben [Intersecting Lives and Families, The Bali, the Filozof, and Me]. Istanbul: Libra Yayınevi.

Bhabha, Homi. 1996. "Culture's In-Between." In Questions of Cultural Identity, edited by Stuart Hall and Paul du Gay, 53-60. London: Sage.

Boym, Svetlana. 2001. The Future of Nostalgia. New York: Basic Books.

Brink-Danan, Marcy. 2012. Jewish Life in 21st-Century Turkey: The Other Side of Tolerance. Bloomington: Indiana University Press.

Buzzard, James. 1997. "Ethnography as Interruption: "News from Nowhere," Narrative, and the Modern Romance of Authority." Victorian Studies 40 (3): 445-474.

Clifford, James and George E. Marcus, eds. 1986. Writing Culture: The Politics and Poetics of Ethnography. Berkeley and Los Angeles: University of California Press.

Eldem, Edhem. 1999. "Istanbul: From Imperial to Peripheralized Capital." In The Ottoman City Between the East and the West: Aleppo, Izmir, and Istanbul, edited by Edhem Eldem, Daniel Goffman, and Bruce Masters, 135-206. Cambridge: Cambridge University Press.

Ender, Rita. 2016. Ismiyle Yasamak [Living with One's Name]. İstanbul: İletişim.

Ender, Rita. 2018. Aile Yadigarları [Family Heirlooms]. Istanbul: İletişim.

Fischer, Michael M. J. 1986. "Ethnicity and Postmodern Arts of Memory." In Writing Culture: The Politics and Poetics of Ethnography, edited by James Clifford and George E. Marcus, 194-233. Los Angeles: University of California Press.

Gabbay, Moris. 2013. Cumhuriyet'le Beraber Büyüdüm [I Grew Up with the Republic]. Istanbul: Türkiye Sosyal Tarih Araștırma Vakfı.

Kuryel, Aylin, and Raşel Meseri. 2018. Türkiye'de Yahudi Olmak: Bir Deneyim Sözlüğü [Being Jewish in Turkey: A Dictionary of Experience]. Istanbul: Iletişim.

Lionnet, Françoise. 1989. Autobiographical Voices: Race, Gender, Self- Portraiture. Ithaca, N.Y: Cornell University Press.

Margulies, Roni. 2000. Gülümser Çocukluğum Ardımdan [My Childhood Smiles After Me]. Istanbul: Adam.

Margulies Roni. 1996. Bilirim Niye Yanık Öter Ney [I Know Why Plaintive is the Flute]. İstanbul: Yap1 Kredi. 
Margulies, Roni. 2006. Bugün Pazar Yahudiler Azar [Jews Go Wild on Sundays]. Istanbul: Kanat. Margulies, Roni. 2018. Ailem ve Diğer Yahudiler [My Family and Other Jews]. Istanbul: Everest. Neyzi, Leyla. 2002. "Remembering to Forget: Sabbateanism, National Identity, and Subjectivity in Turkey." Comparative Studies in Society and History 44 (1): 137-158.

Neyzi, Leyla. 2009. "Eski İstanbul'un şehir kültürünü hatırlamak: yaşanmışlıklar, bellek ve nostalji” ["Remembering the old urban culture of Istanbul: experience, memory, and nostalgia"]. In: Eski İstanbullular ve Yeni Istanbullular, [Old and New Istanbullu] Osmanlı Bankası Arşiv ve Araştırma Merkezi.

Ortner, Sherry B. 2006. Anthropology and Social Theory: Culture, Power, and the Acting Subject. Durham: Duke University Press.

Pamuk, Orhan. 1994. The Black Book. Translated by Güneli Gün. New York: Faber.

Pamuk, Orhan. 2005. Istanbul: Memories of a City. Translated by Maureen Freely. London: FaberFarrar.

Pratt, Mary Louise. 1991. “Arts of the Contact Zone.” Profession Modern Language Association, 33-40.

Pratt, Mary Louise. [1992] 2008. Imperial Eyes: Travel Writing and Transculturation. London: Routledge.

Rodrigue, Aron. 1990. French Jews, Turkish Jews: The Alliance Israelite Universelle and the Politics of Jewish Schooling in Turkey 1860-1925. Bloomington: Indiana University Press.

Roth, Philip. [1993] 1994. Operation Shylock. New York: Vintage.

Rothberg, Michael. 2009. Multidirectional Memory: Remembering the Holocaust in the Age of Decolonization. Stanford: Stanford University Press.

Said, Edward. 1993. "Intellectual Exile: Expatriates and Marginals." Grand Street 47: 112-124.

Şeni, Nora. 2013. "Survival of the Jewish Community in Turkey." In A History of Jewish-Muslim Relations: From the Origins to the Present Day, edited by Abdelwahab Meddeb and Benjamin Stora, 490-496. Princeton: Princeton University Press.

Sertel, Yıldız. 1994. Annem: Sabiha Sertel Kimdi Neler Yazdı [My Mother: Who Was Sabiha Sertel, What Did She Write]. Istanbul: Can Yayınları.

Seyhan, Azade. 2001. Writing Outside the Nation. Princeton: Princeton University Press.

Yerasimos, Stefanos. 1992. "Kozmopolit Yapidan Milliyetçiliğe” ["From a Cosmopolitan Structure to Nationalism”].” In Istanbul 1914-1923, edited by Stefanos Yerasimos, 9-25. Istanbul: Iletişim. 